\title{
Connected in the street: the relation between online social networks, self- esteem and satisfaction with life among individuals experiencing homelessness
}

\author{
Fran Calvo ${ }^{1,2}$, Xavier Carbonell ${ }^{3}$, Oriol Turró ${ }^{4}$ \& Cristina Giralt $^{1}$ \\ ${ }^{1}$ Red de Salud Mental y Adicciones, Institut d'Assistència Sanitària (IAS), Girona \\ ${ }^{2}$ Facultat de Psicologia i Educació, Universitat de Girona \\ ${ }^{3}$ Facultat de Psicologia, Ciències de l'Educació i de l'Esport, Blanquerna, Universitat Ramon Llull, Barcelona \\ ${ }^{4}$ Grupo de investigación sobre envejecimiento, discapacidad y salud. Institut d'Investigació Biomèdica de \\ Girona, IAS, Girona
}

Received: 28-11-2017

Accepted: 29-01-2018

Connected in the street: the relation between online social networks, self-esteem and satisfaction with life among individuals experiencing homelessness

\begin{abstract}
Summary. The universalisation of Social Networking Sites has prompted a debate about whether contact with relatives and friends online has a positive effect on psychological well-being, as it has on direct relationships with primary groups. The aim of this study is to analyze the use of social network sites in a sample of 164 individuals experiencing homelessness (IEH), and to establish the relationship between this usage and their levels of self-esteem and satisfaction with life, using a multiple linear regression model for each dependent variable. The main results show a high prevalence of Internet and social network sites usage amongst IEH, even slightly higher than in the population overall. The variables predicting a higher degree of well-being are related to the use of social network sites, especially keeping in touch with friends. The chronicity associated with length of time on the street is also a key factor. A debate exists regarding the benefits of social network sites on health, and the importance which education may have in improving access to specialized services.
\end{abstract}

Key words: homeless; homelessness; online social networks; self-esteem; satisfaction with life

Connectats al carrer: relació entre les xarxes socials en línia, l'autoestima i la satisfacció amb la vida de persones que experimenten una situació de sensellarisme

Resum. La universalització de les xarxes socials en línia ha provocat un debat sobre si el contacte amb familiars $i$ amics en línia té un efecte positiu en el benestar psicològic, com ho ha fet en les relacions directes amb grups primaris. L'objectiu d'aquest estudi és analitzar l'ús que es fa de les xarxes socials en línia en una mostra de 164 persones que experimenten una situació de sense llar (PES), i establir la relació amb els seus nivells d'autoestima i satisfacció amb la vida, a partir d'un model de regressió lineal múltiple per a cada variable dependent. Els principals resultats mostren una alta prevalença d'ús de llocs d'Internet $i$ xarxes socials entre PES, fins i tot lleugerament més alt que la població general. Les variables predictores d'un major grau de benestar estan relacionades amb l'ús de llocs de xarxes socials, especialment a l'estar en contacte amb amics. La cronicitat associada amb la permanència al carrer és també un factor clau. Hi ha un debat sobre els beneficis de les xarxes socials en línia sobre la salut i la importància que la formació pot tenir per millorar l'accés als serveis especialitzats.

Paraules clau: persones sense llar; sense llar; xarxes socials en línia; autoestima; satisfacció amb la vida

Correspondence

Fran Calvo García

ORCID: 0000-0002-0300-8548

Centre d'Assistència i Seguiment (CAS), c/ Baldiri Reixac, 50

baixos, 17003, Girona (Spain)

fran.calvo@ias.cat 


\section{Introduction}

Subjective well-being is a concept which is hard to delimit, but it is often defined as the development of a person's the overall experience of all areas of health (García \& González, 2000), including physical, psychological, social and spiritual health. Self-esteem and satisfaction with life are seen as two of the principal elements of subjective psychological well-being (Cameron \& Skinner, 2006), and these factors are directly related with the amount of social support a person receives, even so more than with the perception of physical health (Vivaldi \& Barra, 2012). This fact highlights the role of primary relationships such as those with relatives and friends, in allowing individuals to reach a state of adequate overall satisfaction (Montoya \& Londero, 2008).

At a historical moment when the use of Social Networking Sites (SNS) has become nearly universal, part of this contact with one's primary social network is carried out virtually through a range of technological devices and applications. Although obviously with different functioning from face-to-face relationships, one of the predominant uses of SNS is communication with friends and family (Ross, Orr, Sisic, Arseneault, Simmering \& Orr, 2009; Stern \& Taylor, 2007). The use of these networks generates a sense of belonging to a peer group, which motivates continued use (Nadkarni \& Hofmann, 2012).

SNS are defined as a group of Internet-based applications which are built on the technological and ideological foundation of the Web 2.0, allow for the creation and exchange of content created by the users themselves (Kaplan $\&$ Haenlein, 2010). In addition to the most popular SNS such as Facebook, Twitter and Instagram, several authors consider that instant messaging services such as WhatsApp and Line are included under the definition (Schreiner \& Hess, 2015; La Sala, Skues \& Wise, 2014; Yeboah, \& Ewur, 2014), as they share the characteristics of services which allow their users to: i) build a public or semi-public profile in a delimited system; ii) articulate a list of users with whom connection is shared; and iii) see, traverse and communicate through these connections from within the network (Boyd \& Ellison, 2007).

The use of SNS has become so widespread that socially excluded groups with extreme poverty rates and severe social, psychological and physical health issues have also felt the need to belong to the SNS scheme. Individuals experiencing homelessness (IEH) represent a case in point (Eyrich-Garg, 2011), as many of them are among the over one billion people with Facebook profiles or the 700 million on WhatsApp (Castaño, 2015).

Despite suffering from the multiple consequences of a lack of housing and being faced with the need to live on the street or in substandard housing, IEH have also adapted to the changes wrought by social networks, actively engaging with this type of technology (Goodwin \& Myatt, 2013; Humphry, 2014). Their motivations for using this sort of technology tend to be similar to those of the general population (Pollio, Batey, Bender, Ferguson \& Thompson, 2013).

There is a lack of consensus as to whether the use of SNS contributes to bettering people's quality of life or whether on the contrary it tends to worsen it, and there are questions as to what circumstances and conditions might make these outcomes more likely (Shaw \& Gant, 2002; Valkenburg, Peter, \& Schouten, 2006). On the one hand, it has been proven that the communicative activity carried out on SNS reduces feelings of loneliness and enhances individuals' social capital (Burke, Kraut \& Marlow, 2011; Ellison, Steinfield \& Lampe, 2007), which has an effect on levels of selfesteem (Steinfield, Ellison \& Lampe, 2008). This represents an alternative or offers additional support to the relationships of those people who, for various health, geographical or psychological reasons, may have difficulties in maintaining physical or telephone contact with relatives or friends. On the other hand, it appears that the use of these networks can also generate a decrease in long term well-being, unlike direct personal relationships (Kross et al., 2013).

The general aim of this study is to describe the type of Internet use that homeless people engage in, specifically with regard to SNS, and to investigate the potential presence and type of relationship that may exist between this usage and the individuals' self-esteem and satisfaction with life. The hypothesis is that there is a direct relation between being virtually connected to family and friends and a higher degree of SE and SL.

\section{Method}

\section{Definition of Homelessness}

In this study we employ the European Federation of National Organizations Working with Homeless People's definition of a homeless person, which includes individuals who, for different reasons: i) live in the public space without housing; ii) sleep overnight or temporarily in hostels, institutions or shelters; iii) and/ or live in unsafe or inadequate dwellings such as illegal, insalubrious or overcrowded accommodation (FEANTSA, 2006).

\section{Participants}

The study was limited to the area of the city of Girona, (Catalonia), which according to the latest census count (IEC, 2014) had a population of 97,227 inhabitants. In Girona there is one sole municipal hostel for homeless people which offers different social and assistance services. According to official registry, it is estimated that the total number of IEH in the city in 2015 was 270.

According to the population of IEH, $(n=270)$, a sample size was determined, assuming the maximum indetermination principle, $p=\mathrm{q}=.50$, of 150 partici- 
pants, in order to obtain an estimate of the level of self-esteem (SE) and satisfaction with life (SL) and the use of online social networks, with an accuracy of .08.

\section{Instruments}

The Rosenberg Self-Esteem Scale (Rosenberg, 1965). This is a questionnaire consisting of 10 items whose aim is to measure overall self-esteem through the perception of positive and negative feelings toward oneself. The scale is valid and reliable for the Spanish population (Martín-Albó, Núñez, Navarro \& Grijalbo, 2007) and for both genders and different ethnic groups, and it can be applied on a community level (Robins, Hendin \& Trzesniewski, 2011). All the items are answered by choosing from among four Likert-type options according to the level of agreement/disagreement.

The Life Satisfaction Scale (Diener, Emmons, Larsen \& Griffin, 1985). This is a Likert-type scale of five items and five answer options chosen according to level of agreement/disagreement. Its aim is to evaluate the cognitive perception of subjective well-being from the overall assessment that each person makes of his or her own life. The scale has proved to be valid and reliable for male and female adults (Baerger \& McAdams, 1999) and the Spanish population (Atienza, Pons, Balaguer \& García-Merita, 2000).

The Internet and Social Networks Use Habits Test (Muscanell \& Guadagno, 2012). This is a descriptive measure, and it includes a section of basic sociodemographic data and a section about Internet and Social Networks Use Habits. This test was adapted to homeless people including the time variable as an IEH condition and their origin (native or immigrant).

\section{Procedure}

The tests were carried out in November 2015 and January 2016 in the municipal hostel, principally during breakfast and lunch time, coinciding with the time of maximum attendance. The IEH who did not attend the hostel were recruited in the public space by the open medium intervention teams. All IEH found were offered the possibility to be interviewed during the testing period. Seven refused to participate, (generally because of lack of time or scheduling conflicts). The interviews were carried out by professionals and final year Social Education and Psychology students, all of whom had undergone a training process conducted pilot tests with volunteer users who were not included in the study with the aim of reducing the possibilities of bias.

All participants were informed in writing and in different languages of the aims and methods of the study, and they provided consent by signing the handouts. They were also offered the chance to be told about the results of the tests once they were available. The investigation protocol was approved by the Comite de Ética de Investigación Clínica de l'Institut d'Assistència Sanitària (CIEC-IAS) on November 17, 2015.

\section{Design and statistical analysis}

Cross sectional, observational and analytical study. The description of the level of SE and SL was carried out with the use of absolute and relative frequencies. Central tendency and dispersion indicators were used for the description of quantities. Comparisons were carried out between the scores obtained in the SE and SL tests and internet usage and socio-demographic characteristics gathered through the use of contingency tables in qualitative variables and through the comparison of averages with parametric techniques ( $t$-Student or ANOVA) according to variable distribution. A multiple linear regression model was adjusted to determine the variables associated to the levels of SE and SL. The statistical analysis was carried out with the Statistical Package for Social Sciences (SPSS ${ }^{\circledR}$ Inc.; Chicago) v. 21 for Macintosh programme, with a $p=/<0.05$ significant and $95 \%$ confidence interval.

\section{Results}

\section{General Description}

A total of 164 IEH participated in the study, representing $60.7 \%$ of the population of homeless people in Girona. The average age was 42.2 years, $(S D=11.3)$, and the median time spent on the street was, as a condition of IEH, 600 days $\left(\mathrm{Min}=2, \mathrm{Q}_{25}=242, \mathrm{Q}_{75}=\right.$ 2,192, $\operatorname{Max}=3,754)$.

A total of $79.6 \%$ were men $(n=129)$; no differences were found between genders regarding age (Men $=42.6, S D=11.4$ vs. Women $=40.9, S D=11.3 ; t=.97$, $d f=160, p=.33$ ) or the time spent on the street, (Men $=1,156.2$ days, $S D=1,220.4$ vs. Women $=1,460.9$ days, $S D=1,385.8 ; t=-1.2 ; d f=160, p=.21)$. The total proportion of immigrants was $57.4 \%(n=93)$. The immigrants were mostly from North Africa $(41.5 \%, n=68)$, and they were significantly younger than members of the native population, 38.9 years $(S D=10.6)$ vs. 46.7 years $(S D=10.8) ; t=-4.6, d f=160, p<.001)$.

\section{Use of information and communication technologies (ICTs)}

A total of $72.2 \%$ of the sample $(n=117)$ reported using the Internet regularly, and always through the devices located at various public services, as none of the interviewees had their own personal computer.

On the other hand, 37.1\% ( $n=60)$ had mobile phones, all of which except three were smartphones, which they used to access the net via the different free and open wi-fi points in the city. Significant age differences were found regarding the use of the Internet $(\mathrm{M}=45.8$ years $(S D=12.3)$ vs. $\mathrm{M}=40.9$ years $(S D=$ 10.8); $t=2.3, d f=160, p=.023)$. Over half the interviewees (el $53.7 \%, n=87$ ), reported being members of at least one SNS and used them daily or several times a week $(95.4 \%, n=83)$. Most of the interviewees (50\%, $n=81$ ) used mostly Facebook, although some individuals reported having accounts on Youtube $(7.4 \%, n=12)$, 
Table 1. Use of Internet, online social networks and instant Messaging

\begin{tabular}{lc}
\hline Variables & Values (n, \%) \\
\hline Habitual use of Internet & $117(72.2)$ \\
\hline Device & $117(72.2)$ \\
\hline Public computer & $57(35.2)$ \\
\hline Own Smartphone & $3(1.9)$ \\
\hline Tablet & \\
\hline Connection & $60(37)$ \\
\hline Use of uncodified public Wi-fi. & $81(50)$ \\
\hline Municipal shelter for homeless people & $75(46.3)$ \\
\hline Libraries & $54(33.3)$ \\
\hline Civic centres & $51(31.5)$ \\
\hline Principal aim to access Internet & $53(32.7)$ \\
\hline Work search & $12(7.4)$ \\
\hline Search of information & $27(16.7)$ \\
\hline Search for housing & $52(32.1)$ \\
\hline Leisure & $3(1.9)$ \\
\hline Communication with other people & $87(53.7)$ \\
\hline Search for health resources & $81(50)$ \\
\hline Members of Online Social Networks & $12(7.4)$ \\
\hline Facebook & $4(2.4)$ \\
\hline Youtube & $3(1.9)$ \\
\hline Twitter & $42(25.9)$ \\
\hline Google + & $12(53.7)$ \\
\hline Member of Instant Messaging App (Whatsapp) \\
\hline Reason for using SNS & $14(8.6)$ \\
\hline Being in touch with friends & $12(7.4)$ \\
\hline Being in touch with family & \\
\hline Meeting people & \\
\hline Work search & \\
\hline Leisure & \\
\hline
\end{tabular}

Twitter $(2.4 \%, n=4)$ or Google+ $(1.9 \%, n=3)$. A total of $73.7 \%$ of the people who owned a smartphone $(n=42)$ used the instant messaging application WhatsApp to communicate with their contacts (see Table 1).

Regarding the variable measuring the extent to which the use of SNS is the reason for accessing the Internet, the younger people, $(r=-.26, p=.005)$ and those who had spent less time on the street, $(r=-.29$, $p=.013)$ connected more often with the intention of communicating with family members. Differences were found in the comparison of categorical variables related to the use of ICTs and the origin of the individuals. In particular, a higher percentage of immigrants used the Internet, especially to contact friends and family through Facebook, a social network they were more likely than native participants to belong to.

The native-born participants, on the other hand, were more likely to own smartphones and were members of WhatsApp in a significantly higher proportion than immigrants. This proportion is also higher in the use of the application, both to contact family and friends (see table 2).

\section{Self-esteem and Satisfaction with life}

All members of the sample completed the SE and SL scales. The results obtained indicate a positive correlation between the level of SE and the level of SL $(r=.64, p<.001)$.

The bivariate analysis of the dependent variable Degree of SE was significant in the comparison of
Table 2. Association between the characteristics of SNS use and immigration

\begin{tabular}{|c|c|c|c|c|c|c|}
\hline \multirow{2}{*}{$\begin{array}{l}\text { Variables related } \\
\text { to the use of SNS }\end{array}$} & & \multicolumn{2}{|r|}{ Origin } & \multicolumn{3}{|c|}{ Values } \\
\hline & & Immigrant & Autochthonous & $\chi^{2}$ & df & $\mathrm{p}$ \\
\hline \multirow[t]{2}{*}{ Use of Internet } & Yes & 75 & 42 & 7.7 & 1 & .005 \\
\hline & $\mathrm{No}$ & 18 & 27 & & & \\
\hline \multirow[t]{2}{*}{ Has Smartphone } & Yes & 30 & 27 & 4.2 & 1 & .040 \\
\hline & No & 40 & 16 & & & \\
\hline \multirow[t]{2}{*}{ Member of Facebook } & Yes & 60 & 21 & 18.4 & 1 & $<.001$ \\
\hline & No & 33 & 48 & & & \\
\hline \multirow{2}{*}{$\begin{array}{l}\text { Contact with family } \\
\text { Facebook }\end{array}$} & Yes & 48 & 21 & 7.3 & 1 & .007 \\
\hline & No & 45 & 48 & & & \\
\hline \multirow{2}{*}{$\begin{array}{l}\text { Contact with friends } \\
\text { Facebook }\end{array}$} & Yes & 60 & 21 & 18.4 & 1 & $<.001$ \\
\hline & No & 33 & 48 & & & \\
\hline \multirow[t]{2}{*}{ Member of Whatsapp } & Yes & 18 & 24 & 4.09 & 1 & .072 \\
\hline & No & 75 & 45 & & & \\
\hline \multirow{2}{*}{$\begin{array}{l}\text { Contact with family } \\
\text { Whatsapp }\end{array}$} & Yes & 15 & 21 & 4.7 & 1 & .03 \\
\hline & No & 78 & 48 & & & \\
\hline \multirow{2}{*}{$\begin{array}{l}\text { Contact with friends } \\
\text { Whatsapp }\end{array}$} & Yes & 15 & 24 & 7.5 & 1 & .006 \\
\hline & $\mathrm{No}$ & 78 & 45 & & & \\
\hline
\end{tabular}

measures in relation to the independent variables analysed, except in Gender and Origin. Additionally, the bivariate analysis of the dependent variable Degree of $S L$ offered significant results in the comparison of averages with all the independent variables except for Sex and Use of WhatsApp to contact relatives. (See table 3).

Statistically significant correlations were observed with the Age variable (AU: $r=-.32, p=<.001$; SV: $r=-.26$, $p=.001$ ) and Time Spent on the Street. (AU: $r=-.31$, $p=<.001 ; \mathrm{SV}: r=-.26, p=.001)$.

Finally, the multiple linear regression model generated the following as predictors of a higher degree of SE: a higher degree of SE $\left(\mathrm{r}^{2}=.725\right)$ and SL $\left(\mathrm{r}^{2}=.371\right)$, the ones related to connection to SNSs, especially to communicate with friends, not having contact through WhatsApp with relatives, and having spent fewer days on the street as an IEH (See Tables 4 and 5).

\section{Discussion}

This study has described the prevalence of ICT use in a sample of IEH and has analyzed, for the first time in Europe, the relationship between the use of devices and web applications and psychological well-being. The results indicate that the use of Facebook and WhatsApp increases the degree of self-esteem and satisfaction with life. The descriptive data obtained display percentages of Internet use that are similar to the general Spanish population (INE, 2015), and even two points above average as regards SNS connection (INE, 2014).

On the other hand, the only source available for us to analyse the access to information and communication technologies of IEH in a similar context- the city of Madrid (Vázquez, Panadero \& Díaz-Pescador, 2015) - displays lower rates of Internet access and use of SNS than the analyzed sample. This may be due to the fact that immigration in Girona is mostly of North African origin and significantly younger than the native population (UAM, 2016). Taking into account that a younger age is closely related to the habitual use of SNS 
Table 3. Relationship Self Esteem and Life Satisfaction with the principal independent variables

\begin{tabular}{|c|c|c|c|c|c|c|c|c|c|c|}
\hline & \multicolumn{5}{|c|}{ Self esteem (SE) } & \multicolumn{5}{|c|}{ Satisfaction with life (SL) } \\
\hline & $\mathbf{M}$ & SD & $\mathbf{t}$ & df & $\mathrm{p}$ & $\mathbf{M}$ & SD & t & df & $\mathrm{p}$ \\
\hline \multicolumn{11}{|l|}{ Gender } \\
\hline Men & 25.1 & 8.4 & -1.3 & 160 & .237 & 13.1 & 5.1 & -1.2 & 160 & .222 \\
\hline Women & 23.4 & 6.9 & & & & 11.9 & 4.5 & & & \\
\hline \multicolumn{11}{|l|}{ Origin } \\
\hline Immigrant & 24.9 & 6.4 & 2.5 & 125 & .015 & 12.8 & 4.9 & 1.9 & 160 & .057 \\
\hline Autochthonous & 22.1 & 8.1 & & & & 11.4 & 4.2 & & & \\
\hline \multicolumn{11}{|l|}{ Qualifications } \\
\hline Higher & 28.9 & 2.6 & 5.1 & 16.9 & .05 & 12.1 & 4.7 & 2.8 & 10.9 & .05 \\
\hline Basic & 23.4 & 7.4 & & & & 15.1 & 2.9 & & & \\
\hline \multicolumn{11}{|l|}{ Internet } \\
\hline User & 26.9 & 5.5 & 15.3 & 117 & $<.001$ & 13.6 & 4.4 & 8.5 & 126 & $<.001$ \\
\hline Non user & 15.4 & 3.7 & & & & 8.6 & 2.8 & & & \\
\hline \multicolumn{11}{|l|}{ SNS } \\
\hline User & 29.5 & 3.6 & 20.8 & 160 & $<.001$ & 14.6 & 4.4 & 8.6 & 156 & $<.001$ \\
\hline Non user & 17.1 & 3.9 & & & & 9.4 & 3.2 & & & \\
\hline \multicolumn{11}{|l|}{ Facebook } \\
\hline User & 29.7 & 3.7 & 17.7 & 151 & $<.001$ & 14.9 & 4.2 & 9.2 & 150 & $<.001$ \\
\hline Non user & 17.8 & 4.7 & & & & 9.9 & 3.2 & & & \\
\hline \multicolumn{11}{|c|}{ Contact with family Facebook } \\
\hline Yes & 29.5 & 3.9 & 12.6 & 156.1 & $<.001$ & 14.9 & 4.2 & 9.2 & 16 & $<.001$ \\
\hline No & 19.5 & 6.2 & & & & 9.9 & 3.2 & & & \\
\hline \multicolumn{11}{|c|}{ Contact with Friends Facebook } \\
\hline Yes & 29.7 & 3.7 & 17.7 & 151 & $<.001$ & 14.9 & 4.2 & 9.2 & 16 & $<.001$ \\
\hline No & 17.8 & 4.7 & & & & 9.9 & 3.2 & & & \\
\hline \multicolumn{11}{|l|}{ Whatsapp } \\
\hline User & 29.5 & 4.6 & 8.2 & 108.9 & $<.001$ & 13.9 & 4.4 & 2.8 & 160 & .005 \\
\hline Non user & 21.7 & 6.9 & & & & 11.6 & 4.6 & & & \\
\hline \multicolumn{11}{|c|}{ Contact with family Whatsapp } \\
\hline Yes & 29.7 & 3.7 & 17.7 & 151 & $<.001$ & 13.3 & 4.2 & 1.6 & 160 & .117 \\
\hline No & 17.8 & 4.7 & & & & 11.9 & 4.7 & & & \\
\hline \multicolumn{11}{|c|}{ Contact with friends Whatsapp } \\
\hline Yes & 29.9 & 4.6 & 8.4 & 96.5 & $<.001$ & 13.9 & 4.6 & 2.7 & 160 & .009 \\
\hline No & 21.8 & 6.9 & & & & 11.7 & 4.5 & & & \\
\hline
\end{tabular}

Table 4. Multiple linear regression model: Self esteem

\begin{tabular}{lccc}
\hline Variables & \multicolumn{3}{c}{ Values } \\
\cline { 2 - 4 } & $\boldsymbol{B}$ & $\mathbf{t}$ & $\mathrm{p}$ \\
\hline Contact with friends Facebook & .747 & 15.7 & $<.001$ \\
\hline Contact with friends Whatsapp & .437 & 5.2 & $<.001$ \\
\hline Contact with family Whatsapp & -.284 & -3.5 & .001 \\
\hline Days as IEH & -.099 & -2.3 & .025 \\
\hline Qualifications & -.042 & -2.4 & .153 \\
\hline Contact with family Facebook & -.039 & -.436 & .663 \\
\hline Gender & .039 & .911 & .364 \\
\hline Age & .031 & .628 & .531 \\
\hline Origin & .005 & .094 & .925 \\
\hline
\end{tabular}

Table 5. Multiple linear regression model: Satisfaction with life

\begin{tabular}{lccc}
\hline \multirow{2}{*}{ Variables } & \multicolumn{3}{c}{ Values } \\
\cline { 2 - 4 } & $\mathrm{B}$ & $\mathrm{t}$ & $\mathrm{p}$ \\
\hline Contact with family Facebook & .465 & 6.8 & $<.001$ \\
\hline Days as IEH & -.180 & -2.6 & .009 \\
\hline Gender & .102 & 1.5 & .135 \\
\hline Age & -.125 & -1.1 & .292 \\
\hline Origin & .030 & .43 & .666 \\
\hline Qualifications & .072 & 1.1 & .292 \\
\hline Contact with friends Whatsapp & -.005 & -.07 & .944 \\
\hline
\end{tabular}

(Domínguez, 2010, Vidal, Martínez, Fortuño \& Cervera, 2011), we would argue that the presence of these younger immigrants influenced the frequent use of
ICT, as is the case in other young IEH samples (Guadagno, Muscanell \& Pollio, 2013).

As regards the degree of influence of SNS use on self-esteem and life satisfaction, it is worth pointing out the link between greater attempts to keep in touch with friends and increased self-esteem and life satisfaction, a trend that was evident regardless of the device or type of social network used (Facebook or WhatsApp). In this sense, as other studies indicated, maintaining a virtual connection with friends increases well-being, and it acts as a protective factor against the appearance of symptomatology of certain mental issues or disorders (Rice, Kurzban, \& Ray 2012; Wilhem, Wedgwood, Parker, Geerligs \& Hadzi-Pavlovic, 2010).

The perception of social support has an influence on somatic functioning and is a highly effective resource when confronting stress, as it mitigates its adverse effects, and has a positive influence on the symptomatology of chronic illnesses (Rice, Kurzhan, $\&$ Ray, 2012; Barra, 2004). This support through Web 2.0 resources makes possible or facilitates long-distance contact when geographic, temporal or interpersonal circumstances make face-to-face communication difficult or impossible (Rubio \& Perlado, 2015). This allows IEH to express their opinions freely, and it makes them feel they are participants in a peer group, even while 
they are dealing with an extremely hostile environment. Consequently, the participants achieved the benefits of those elements of online personal communication online that have been shown to exert a protective influence effect on mental and physical health (A. Yarcheski, Mahon, T.J. Yarcheski, \& Cannella, 2004). As regards the specific use of WhatsApp, we have observed that its use is related to a higher degree of selfesteem, and, to a lower degree but also significantly, the level of life satisfaction. An especially curious finding was the inverse relation between connections with family through WhatsApp and self-esteem.

The causes of homelessness are complex and are related to structural causes, both institutional and individual, and relational causes (Cabrera \& Rubio, 2008). These latter sorts of problems are of great importance in the multi-problematic escalation that people suffer prior to losing their housing and living on the street. This process generates or worsens a high percentage of problems related to drug consumption and dual pathology (Tronchoni, Aparicio, García \&Noriega, 2003). These disorders have an impact on the inner circles of the people suffering from them, most often their families. This leads to the interpretation that the degree of self-esteem might diminish with greater contact with the family via WhatsApp because of a greater potential for the continuation of conflict which could have arisen among family members. Consequently, the type of communication generated on the mobile device, which is more accessible than the fixed devices, could amplify those elements of the relation that lead to the reduction in well-being.

This fact also correlates with the differences in the use of WhatsApp found according to the individuals' places of origin. In this respect, although we do not have studies which offer a definitive answer, it is highly probable that the reasons why an IEH does not have housing are different according to origin.

The causes of immigration from non-EU countries to the EU are often strongly linked to the need to improve life conditions in countries of origin, and the distance from family is generally motivated by the migratory process (Banda \& Gómez, 2015; Gonzálvez, 2010; Requena \& Sánchez-Dominguez, 2011). Meanwhile, distance from family amongst the native population is initially prompted by other factors. Immigrants, who tended to use WhatsApp less and were not as likely to have mobile phones did not display the negative correlation between family contact and SE to the same extent as the native population.

Additionally, the study found a connection between the time spent on the street and the decreased levels of self-esteem and life satisfaction. It is a well-known fact that there is a risk of physical and mental disease becoming chronic due to lengthened exposure to conditions of extreme vulnerability suffered as a consequence of homelessness (North, Pollio, Smith \& Spitznagel, 1998). This fact may contribute to the general deterioration of the individual's self-perception of their lifestyle. However, we must consider the op- portunities that arise from high Internet connectivity in the analysed sample. It is worth investigating possible actions and interventions related to ICTs and how they can be applied for psychoeducation purposes. They may contribute to the improvement of people who suffer chronic illnesses, as it has been proved that they reduce the impact of the symptomatology (Stellefson, Alber, Wang, Eddy, Chaney \& Chaney, 2015).

Finally, it is worth highlighting that this study has limitations. Firstly, it would have been interesting to carry out a longitudinal study including an experimental situation which consisting of a digital alphabetization program in order to test its influence on self-esteem and life satisfaction. This is a hypothesis to develop in the future. Furthermore, it was not possible to determine more specifically the content of the individuals' online communication, nor the other uses they make of SNSs such as leisure. Knowing this would have qualitatively complemented the information gathered. Furthermore, a certain social desirability is assumed, since the users have a perception of what they think they should answer and wish to please the professionals working with them or to give responses considered politically correct. Additionally, even though we consider that one of the strong points of this article is the high percentage of recruitment in relation to the total population, we struggled to access the IEH living in illegally occupied houses.

In conclusion, this study points out the potentialities and opportunities in the use of ICTs and SNSs to improve the conditions of IEH, based on their capacity to have a positive influence on psychological wellbeing through the network of peer support. It is necessary for the services involved in the attention and care for IEH to develop community and individual-oriented programmes promote the healthy use of ICTs and SNSs. The benefits observed suggest that such programmes could help to reduce social inequality and improve these individuals' quality of life.

\section{Conflict of interest statement}

None declared.

\section{Special thanks}

To Claudia García, Joan Mestres and Bárbara Argemí for their participation in the recruitment of the participants and data collection, to Carles Fàbregas, Irene Ribugent and Maite Tixis of the Centre d'Acolliment $i$ Serveis Socials "la Sopa" in Girona for giving access to the participants of this study.

\section{References}

Atienza, F.L., Pons, D., Balaguer, I., \& García-Merita, M.L. (2000). Propiedades psicométricas de la Escala de Satisfacción con la Vida en adolescentes. Psicothema, 12, 331-336.

Baerger, D.R., \& McAdams, D.P. (1999). Life story co- 
herence and its relation to psychological well-being. Narrative Inquiry, 9, 69-96. doi: 10.1075/ni.9.1.05bae. Banda, A., \& Gómez, J.A. (2015). Evolución de la inmigración en España 1998-2014, aportes y el reto a futuro. Pensamiento al margen, 2, 1-19.

Barra, E. (2004). Apoyo social, estrés y salud. Psicología y salud, 14(2), 237-243.

Boyd, D. M., \& Ellison, N.B. (2007). Social Network Sites: Definition, history and scholarship. Journal of Computer-Mediated Communication, 13(1), 210-230. doi: 10.1111/j.1083-6101.2007.00393.x.

Burke, M. Kraut, R., \& Marlow, C. (2011). Social network activity and social well-being. Proceedings of the 2010: Annual Conference on Humans Factors in Computing Systems, 1909-1919. New York. doi:10.1145/ 1753326.1753613.

Cabrera, P. J., \& Rubio, M. J. (2008). Las personas sin hogar, hoy. Revista del Ministerio de Trabajo e Inmigración, 75, 51-74.

Cameron, D.N., \& Skinner, H.A. (2006). eHEALS: The eHealth Literacy Scale. Journal of Medical Internet Research, 8(4), e27. doi: 10.2196/jmir.8.4.e27.

Castaño, L.C. (2015). WhatsApp y la búsqueda del control de la situación informacional por parte de los jóvenes. Sphera Pública, 15, 76-96.

Diener, E.D., Emmons, R.A., Larsen, J.R., \& Griffin, S. (1985). The satisfaction with life scale. Journal of Personality Assessment, 49, 71-75. doi: 10.1207/ s15327752jpa4901_13.

Domínguez, D.C. (2010). Las redes sociales: tipología, uso y consumo de las redes 2.0 en la sociedad digital actual. Documentación de las Ciencias de la Información, 33, 45-68.

Ellison, N., Steinfield, C., \& Lampe, C. (2007). The benefits of Facebook "friends:" Social capital and college students' use of online social network sites. Journal of Computer-Mediated Communication, 12, 1143-1168. doi: 10.1111/j.1083-6101.2007.00367.x.

Eyrich-Garg, K.M. (2011). Sheltered in cyberspace? Computer use among the unsheltered "street" homeless. Computers in Human Behavior, 27, 296-303. doi: 10.1016/j.chb.2010.08.007.

FEANTSA. (2006). ETHOS Tipology on homelessness and housing exclusion. European Federation of National Organizations working with the Homeless Web-Site. Retrieved February 15 of 2015 from http://www. feantsa.org/spip.php?rubrique175\&lang=en .

García, C., \& González, I. (2000). La categoría de bienestar psicológico. Su relación con otras categorías sociales. Revista Cubana de Medicina General Integral, 16(6), 586-592.

Goodwin-Smith, I., \& Myatt, S. (2013). Homeless and the role of Information Technology in staying connected. Department of Families, Housing Community Services and Indigenous Affairs, Australian Government, Evidence Note, 55.

Gonzálvez V. (2010). Los extranjeros residentes en España: Su aportación a la demografía. Investigaciones Geográficas, 52, 99-135.

Guadagno, R.E., Muscanell, N.L., \& Pollio, D.E. (2013).
The homeless use Facebook?! Similarities of social network use between college students and homeless young adults. Computers in Human Behavior, 29, 8689. doi: 10.1016/j.chb.2012.07.019.

Humphry, J. (2014). Homeless and connected: Mobile phones and the Internet in the lives of homeless Australians. University of Sydney: Australia.

IEC, Idescat. (2015). Censo de la ciudad de Girona. Retrieved october 28 of 2016 from: http://www. idescat.cat/emex/?id=170792\&lang=es.

INE (2014). Encuesta sobre equipamiento y uso de Tecnologías de Información y Comunicación en los Hogares. Notas de prensa. Instituto Nacional de Estadística. Retrieved February 12 of 2016 from http:// www.ine.es/prensa/np864.pdf

INE (2015). Encuesta sobre equipamiento y uso de Tecnologías de Información y Comunicación en los Hogares. Notas de prensa. Instituto Nacional de Estadística. Retrieved February 12 of 2016 from http:// www.ine.es/prensa/np933.pdf.

Kaplan, A.M., \& Haenlein, M. (2010). Users of the world, unite! The challenges and opportunities of social media. Business Horizons, 53(1), 59-68. doi: 10.1016/j.bushor.2009.09.003.

Kross, E., Verduyn, P., Demiralp, E., Park, J., SeungjaeLee, D., Lin, N., Shablack, H., Jonides, J., \& Ybarra, O. (2013). Facebook use predicts declines in subjective well-being in young adults. PLOS ONE, 8(8). doi: 10.1371/journal.pone.0069841.

La Sala, L., Skues, J., \& Wise, L. (2014). What do we mean by social networking sites? In Wiederhold, B.K., \& Fiva, G. (Eds.), Annual Review of Cybertherapy and Telemedicine, 199, 108-128. EEUU: IOS Press Books.

Martín-Albo, J., Núñez, J.L., Navarro, J.G., \& Grijalbo, F. (2007).The Rosemberg Self-Steem Scale: Translation and validation in university students. The Spanish Journal of Psychology, 10(2), 458-467.

Montoya, B., \& Londero, R. (2008). Satisfacción con la vida y autoestima en jóvenes de familias monoparentales y biparentales. Psicología y Salud, 18(1), 117122.

Muscanell, N.L., \& Guadagno, R.E. (2012). Make new friends or keep the old: Gender and personality differences in social networking use. Computers in Human Behavior, 28, 107-112. doi: 10.1016/j. chb.2011.08.016.

Nadkarni, A., \& Hofmann, S.G. (2012). Why do people use Facebook? Personality and Individual Differences, 52(3), 243-249. doi: 10.1016/j.paid.2011.11.007.

North, C.S., Pollio, D.E., Smith, E.M., \& Spitznagel, E.L. (1998). Correlates of early onset and chronicity of homelessness in a large urban homeless population. The Journal of Nervous and Mental Disease, 186(7), 393-400.

Pollio, D.E., Batey, S., Bender, K., Ferguson, K., \& Thompson, S. (2013). Technology use among emerging adult homeless in two U.S. Cities. Social work, 58(2), 173-175. doi: 10.1093/swt/swt006.

Requena, M., \& Sánchez-Domínguez, M. (2011). Las familias inmigrantes en España. Revista Internacional 
de Sociología, 69, 79-104. doi:10.3989/ris.2011. iM1.387.

Rice, E., Ray, D., \& Kurzban, S. (2012). Homeless but connected: The role of heterogeneous social network ties and social networking technology in the mental health outcomes of Street-living youth. Community Mental Health Journal, 48(6): 692-698. doi: 10.1007/ s10597-011-9462-1.

Robins, R.W., Hendin, M.H., \& Trzesniewski, K.H. (2011). Measuring global self-steem: Construct validation of a single-item measure and the Rosemberg Self-Steem Scale. Personality and Social Psychology Bulletin, 27(2), 151-161. doi: 10.1177/0146167201272002.

Rosenberg, M. (1965). Society and the adolescent selfimage. Princeton, NJ: Princeton University Press. doi: $10.1017 / \mathrm{S} 1138741600006727$.

Ross, C., Orr, E.S., Sisic, M., Arseneault, M.J., Simmering, M.G., \& Orr, R.R. (2009). Personality and motivations associated with Facebook use. Computers in Human Behavior, 25(2), 578-586. doi: 10.1016/j. chb.2008.12.024.

Rubio, J., \& Perlado, M. (2015). The WhatsApp phenomenon in the context of personal communication: an aproximation through the university youths. Icono 14, 13, 73-94. doi: 10.7195/ri14.v13i2.818.

Schreiner, M., \& Hess, T. (2015). Examining the role of privacy in virtual migration. The case of Whatsapp and Threema. AIS Electronic Library, 33. Universität München: Germany.

Shaw, B., \& Gant, L. (2002). In defense of the Internet: The relationship between Internet communication and depression, loneliness, self-esteem, and perceived social support. CyberPsychology \& Behavior, 5, 157-171. doi:10.1089/109493102753770552.

Steinfield, C., Ellison, N.B., \& Lampe, C. (2008). Social capital, self-steem, and use of onlilne social network sites: A longitudinal analysis. Journal of Applied Developmental Psychology, 29, 434-445. doi: 10.1016/j. appdev.2008.07.002.

Stellefson, M., Alber, J.M., Wang, M.Q., Eddy, J.M., Chaney, B.H., \& Chaney, D. (2015). Use of health information and communication technologies to promote health and manage behavioral risk factors associated with chronic disease: Applications in the field of health education. American Journal of Health Education, 46, 185-191. doi: 10.1080/19325037.2015.1043064.

Stern, L.A., \& Taylor, K. (2007). Social networking on Facebook. Journal of the Communication, Speech, and Theatre Association of North Dakota, 20, 9-20.

Tronchoni, M., Aparicio, V, García, E \& Noriega, M. (2003). Prevalencia de patología mental entre poblacion sin hogar. Cuadernos de psiquiatría comunitaria, 3(2), 129- 147.

UAM. (2016). Observatorio de la Inmigración Marroquí en España - Atlas 1996. Retrieved January 20 of 2016 from https://www.uam.es/otroscentros/TEIM/Observainmigra/Atlas\%201996\%20inicio.htm.

Valkenburg, P. M., Peter, J., \& Schouten, A. P. (2006). Friend networking sites and their relationship to adolescents' well being and social self-esteem. $C y$ berPsychology and Behavior, 9, 584-590. doi: 10.1089/ cpb.2006.9.584.

Vázquez, J.J., Panadero, S., Martín, R. \& Díaz, MdV. (2015). Access to new information and communication technologies among homeless people in Madrid (Spain). Journal of Community Psychology, 43(3), 338347. doi: 10.1002/jcop.21682

Vidal, C.E., Martínez, J.C., Fortuño, M.L., \& Cervera, M.G. (2011). Actitudes y expectativas del uso educativo de las redes sociales en los alumnos universitarios. RUSC. Universities and Knowledge Society Journal, $8(1), 171-185$.

Vivaldi, F., \& Barra, E. (2012). Bienestar psicológico, apoyo social percibido y percepción de la salud en adultos mayores. Terapia Psicológica, 30(2), 23-29.

Wilhelm, K., Wedgwood, L., Parker, G., Geerligs, L., \& Hadzi-Pavlovic, D. (2010). Predicting mental health and well-being in adulthood. The Journal of Nervous and Mental Disease, 198, 85-90. doi: 10.1097/ NMD.0b013e3181cc41dd.

Yarcheski, A., Mahon, N. E., Yarcheski, T. J., \& Cannella, B. L. (2004). A meta-analysis of predictors of positive health practices. Journal of Nursing Scholarship, 36(2), 102-108. doi: 10.1111/j.1547-5069.2004.04021.x.

Yeboah, J., \& Ewur, G.D. (2014). The impact of Whatsapp Messenger usage on students performance in tertiary institutions in Ghana. Journal of Education and Practice, 5(6), 157-164. 